Syi’ar Vol. 18 No. 1 Januari-Juni 2018

\title{
KESEIMBANGAN EMOSI DAN KESEHATAN MENTAL MANUSIA DALAM PERSFEKTIF PSIKOLOGI AGAMA
}

\author{
Rossi Delta Fitrianah*
}

Emotion is a situation caused by a particular situation (special), and emotions tend to occur in relation to behavior that leads (approach) or avoid (avoidance) to something, and the behavior is generally accompanied by physical expression, so that others can know that someone is experiencing emotions. Emotional balance is called emotional stability, a characteristic of someone who has good emotional control. Sometimes it is also termed emotional maturity, which is a state of achieving maturity from emotional development. Mental health in human life is a very important problem because it concerns the quality and happiness of humans. Without good health, people will not be able to get happiness and high quality human resources. Mental health in human life is a very important problem because it concerns the quality and happiness of humans. Without good health, people will not be able to get happiness and high quality human resources. This is because those who can guarantee human happiness are the psychology, health and diversity that humans have.

Key Word: Emotional Balance, Mental Health, Religion Psychology

\section{A. Pendahuluan}

Berbicara mengenai manusia adalah persoalan yang tidak habis habisnya untuk didiskusikan. Dalam berbagai aliran psikologi, seperti psikoanalisa (klasik) Sigmund Freud memandang bahwa prilaku manusia banyak dipengaruhi oleh masa lalu, alam tak sadar, dorongan dorongan biologis yang selalu menuntut kenikmatan untuk segera dipenuhi. Jadi tak heran bila psikoanalisa menganggap hakikat manusa adalah buruk, liar, kejam, non etis , egois ,sarat nafsu dan berkiblat pada kenikmatan jasmani $^{1}$

*Penulis adalah Dosen Jurusan Dakwah IAIN Bengkulu
Sementara menurut Quraish shihab dalam wawasan al qur'an hal tersebut disebabkan pembahasan tentang manusia terlambat dilakukan karena perhatian awal tertuju pada alam materi dan ciri khas akal manusia yang cenderung menghindari memikirkan yang kompleks atau sifat akal manusia yang tidak mampu mengetahui hakekat hidup. ${ }^{2}$

Namun ahli psikologi humanistic cenderung menolak sepenuhnya gagasan bahwa sifat manusia bias dipelajari secara ilmiah sementara menurut ahli psikologi memberikan penertian psikologi adalah ilmu yang mempelajari perilaku manusia 
baik yang tampak maupun tak tampakkarena perilaku manusia merupakan perwujudan dari gejala gejala kejiwaan ${ }^{3}$

Selanjutnya jika berbicara tentang Emosi pada umumnya disifatkan sebagai keadaan (state) yang ada pada individu atau organisme pada suatu waktu. Emosi berlangsung dalam waktu yang relatif singkat, sehingga emosi berbeda dengan mood. Mood atau suasana hati pada umumnya berlangsung dalam waktu yang relatif lebih lama dari pada emosi, tetapi intensitasnya kurang apabila dibandingkan dengan emosi. Oleh karena itu sering dikemukakan bahwa emosi merupakan keadaan yang ditimbulkan oleh situasi tertentu(khusus), dan emosi cenderung terjadi dalam kaitannya dengan perilaku yang mengarah (approach) atau menyingkir (avoidance) terhadap sesuatu, dan perilaku tersebut pada umumnya disertai adanya ekspresi kejasmanian, sehingga orang lain dapat mengetahui bahwa seseorang sedang mengalami emosi.

Namun demikian kadang-kadang orang masih dapat mengontrol keadaan dirinya sehingga emosi yang dialami tidak tercetus keluar dengan perubahan atau tanda-tanda kejasmanian tersebut. Hal ini berkiatan dengan pendapat yang dikemukakan oleh Ekman dan Friesen. Menurut Ekman dan Friesen ada tiga rules, yaitu masking,

modulation, dan samulation.

Masking adalah keadaan seseorang yang dapat menyambunyikan atau dapat menutupi emosi yang dialaminya. Emosi yang dialaminya tidak tercetus keluar melalui ekspresi kejasmaniannya. Misalnya orang yang sangat sedih karena kehilangan anggota keluarganya. Kesedihan tersebut dapat diredam atau dapat ditutupi, dan tidak adanya gejala kejasmanian yang menyababkan tampaknya rasa sedih tersebut. Pada modulasi (modulation) orang tidak dapat meredam secara tuntas mengenai gejala kejasmaniannya, tetapi hanya dapat mengurangi saja. Jadi misalnya karena sedih, ia menangis (gejala kejasmanian) tetapi tangisannya tidak begitu mencuatcuat. Pada simulasi(simulation) orang tidak mengalami emosi, tetapi seolah-olah mengalami emosi dengan menampakan gejala-gejala kejasmanian. ${ }^{4}$

\section{B. Macam-Macam Emosi}

Atas dasar aktivitasnya, tingkah laku emosiaonal dapat dibagi menjadi beberapa bagian yaitu: takut, cemburu, gembira, marah dan cinta. ${ }^{5}$

1. Takut

Pada dasarnya, rasa takut itu bermacam-macam. Ada yang timbul karena seorang anak kecil memeang ditakut-takuti atau karena berlakunya 
berbagai pantangan dirumah. Akan tetapi, ada juga rasa takut "naluriah" yang terpendam dalam hati sanubari setiap insan. Misalnya saja, rasa takut akan tempat gelap, takut berada ditempat sepi tanpa teman, atau takut menghadapi halhal asing yang tidak dikenal. Kengeriankengerian ini relative lebih banyak di derita oleh anak-anak daripada orang dewasa. Karena, sebagai insane yang masih sangat muda, tentu saja daya tahan anak-anak belum kuat.

Jika dilihat secara objektif, bisa dikatakan bahwa rasa takut selain mempunyai segi-segi negative, yaitu bersifat menggelorakan dan menimbulkan perasaan-perasaan dan gejala tubuh yang menegangkan, juga ada segi positifnya. Rasa takut merupkan salah satu kekuatan utama yang mendorong dan menggerakannya. Reaksi yang timbul di dalam individu, lalu menggerakan individu untuk melindungi diri terhadap rangsangan atau bahaya dari luar, menjauhkan diri dari sesuatu yang dapat menyakiti diri, melukai diri, atau menimbulkan bahaya lainnya.

Dengan demikian, jelaslah bahwa rasa takut mempunyai nilai negative dan positif. Positif karena rasa takut melindungi individu dalam keadaan yang berbahaya.

2. Cemburu
Kecemburuan adalah bentuk khusus dari kekhawatiran yang didasari oleh kurang adanya keyakinan terhadap diri sendiri dan ketakutan akan kehilangan kasih sayang dari seseorang. Seseorang yang cemburu selalu mempunyai sikap benci terhadap saingannya.

\section{Gembira}

Gembira adalah ekspresi dari kelegaan, yaitu perasaan terbebas dari ketegangan biasanya kegembiraan disebabkan oleh hal-hal yang bersifat tibatoba (surprise) dan kegembiraan biasanya bersifat social, yaitu melibatkan orangorang lain di sekitar orang yang sedang genbira tersebut.

\section{Marah}

Sumber utama kemarahan adalah hal-hal yang mengganggu aktivitas untuk sampai pada tujuannya. Dengan demikian,ketegangan (stress) yang terjadi dalam aktivitas itu tidak mereda, bahkan bertambah. Untuk menyalurkan ketegangan-ketegangan itu individu yang bersangkutan menjadi marah.

\section{Cinta}

Apakah cinta? Sesungguhnya betapa sulitnya kita untuk menjelaskan kata yang stau ini. Sama halnya ketika kita harus mendefeniisikan ihwal kebahagiaan. Penyair mesir, Syauqi Bey, melukiskan "cinta" dalam sebuah sajaknya:

Apakah cinta 
Mulanya berpandangan mata

Lantas saling senyum

Kata berbalas kata

Dan memadu janji

Akhirnya bertemu

Namun yang digambarkan di atas adalah cinta romantic, yaitu cinta waktu pacaran yang kadang-kadang berakhir putus setelah puas bertemu dalam memadu cinta, tidak sampai meningkat kejenjang pernikahan. Adapun cinta yang tumbuh dalam pernikahan adalah lebih kuat dan lebih agung, karena tuhan yang menciptakannya untuk menjalin pernikahan itu menjadi kekal, tidak gampang diputuskan.

Setiap orang, anak-anak maupun orang dewasa, pada hakikatnya menginginkan untuk diterima sebagaimana adanya, dirinya, fisiknya, juga pribadinya secara keseluruhan dalam keluarga, termasuk diantaranya dapat menerima kelemahan dan kekurangan mereka.

Tuhan telah menciptakan makhluknya sedemikian rupa, sehingga sudah merupakan hukum alam bahwa anak-anak membutuhkan dan selalu mendambakan cinta kasih orang tua. Kebutuhan emosi seorang anak terhadap cinta dan kasih sayang, sama besarnya dengan kebutuhan fisik akan makanan. ${ }^{6}$

\section{Keseimbangan Emosi}

Dalam kamus Psikologi, keseimbangan emosi disebut dengan emotional stabilty, karakteristik seseorang yang memiliki kontrol emosional yang baik. Terkadang diistilahkan juga dengan emotional maturity (kedewasaan emosional), yaitu satu keadaan mencapai tingkat kedewasaan dari perkembangan emosional. Sebaliknya, emosi yang tidak seimbang (Al-waswasu) dapat mengakibatkan kecemasan (anxiety), kegelisahan (nerveus), kekawatiran yang berlebih dan sikap tak bertanggung jawab. Kondisi semacam ini bisa menghambat sistem kerja otak menalar setiap masalah secara optimal. Sehingga dapat menyebabkan kebimbangan yang berlarut.

Allah SWT dalam surat An Anas mengajarkan setiap hamba untuk memohon perlindungan kepada-Nya agar terhindar dari keadaan al-waswas. Permohonan dalam surat itu menggunakan tiga sifat sekaligus, yaitu Rabbin Nas, Malikin Nas dan Ilahin Nas. Kata Rabb, bermakna pemelihara, pendidik dan pencipta yang berkonotasi dengan sifat kasih-sayang; Malik, bermakna raja dan penguasa dengan kesan bijaksana, tegas dan adil; dan Ilah berkenaan dengan ubudiyah dan keyakinan. Ketiga sifat itu digunakan untuk memohon perlindungan 
Syi'ar Vol. 18 No. 1 Januari-Juni 2018

dari satu masalah saja, yaitu Al waswas fi shudurin nas.

Al-waswas secara bahasa berarti bisikan-bisikan suara halus yang merasuk dalam sanubari. Dengan bahasa sederhana, bisa dipahami sebagai rangkaian situasi emosional yang tidak seimbang yang kerap menyesakkan dada. Keseimbangan emosi merupakan ciri pribadi yang sehat. Keseimbangan emosi menjadi faktor terpenting bagi efektifitas nalar untuk mampu bekerja secara baik. Al Qur'an menilai bahwa menjaga keseimbangan emosi (al kadziminal ghaidh) adalah ciri dari ketakwaan. Demikian pula Rasulullah SAW memuji dan menyebut orang yang dapat menjaga emosi sebagai orang yang kuat, diriwayatkan dari Abu Hurairah bahwa Rasulullah SAW pernah bersabda, "bukanlah orang kuat itu adalah orang yang hebat bergulat, tapi orang yang kuat adalah orang yang dapat menahan emosinya ketika ia marah" (HR Bukhari dan Muslim)

Al Qur'an mencela orang yang demikian, "mereka dalam keadaan raguragu antara yang demikian, tidak masuk kepada golongan ini dan tidak (pula) kepada golongan itu Rasulullah SAW selalu memperingatkan sahabatnya, "Jangan suka marah (emosi)." Sahabat itu terus bertanya dan Nabi SAW berulang kali berpesan, "Jangan suka marah."(HR.Bukhari) Situasi semacam ini bisa ditimbulkan oleh faktor internal meliputi tingkat kematangan emosi, pola berfikir dan kualitas keyakinan (iman). Dapat pula disebabkan adanya pengaruh kuat dari faktor eksternal(bisikan jin atau perilaku orang lain.

Dalam kondisi seperti itu, seseorang tidak sepantasnya mengambil suatu keputusan, sebab sikap yang diputuskan dalam situasi demikian hanya akan menciptakan masalah yang lebih rumit. Dalam hadits riwayat Abu Bakrah, Rasululah SAW bersabda, "seseorang janganlah memutuskan perkara antara dua orang sedang ia dalam keadaan marah" (HR Bukhari dan Muslim).

\section{Definisi Kesehatan Mental}

Pola negatif (salabiy), bahwa kesehatan mental adalah terhindarnya seseorang dari segala neurosis (al-amradh al-ashabiyah) dan psikosis (al-amradh aldzihaniyah). Kedua, pola positif (ijabiy), bahwa kesehatan mental adalah kemampuan individu dalam penyesuaian diri sendiri dan terhadap lingkungan sosialnya.

Zakiah Daradjat secara lengkap mendefinisikan kesehatan mental dengan "terwujudnya keserasian yang sungguh- 
sungguh antara fungsi-fungsi kejiwaan dan terciptanya penyesuaian diri antara individu dengan dirinya sendiri dan lingkungannya berdasarkan keimanan dan ketakwaan",

Menurut C. Maninger sehat mental merupakan penyesuaan manusia terhadap dunia lingkungannnya dan terhadap diri orang lain dengan keefektifan dan kebahagiaan yang maksimum. ${ }^{8}$

Sedangkan kesehatan mental dalam Islam berhubungan dengan konsep kebahagiaa. Sumber kebahagiaan manusia dating dari dua arah, yaitu dari manusia dan dari tuhan ${ }^{9}$ Jadi kesehatan mental adalah dimana seseorang mampu beradaptasi dengan lingkungan dan orang orang disekitarnya mampu membuat bahagia diri sendiridan orang lain.

Kenapa hal itu bisa terjadi? Jawabannya karena kesehatan mental tersebut menyangkut segala aspek kehidupan yang menyelimuti manusia mulai dari kehidupan pribadi, keluarga, sosial, politik, agama serta sampai pada bidang pekerjaaan dan profesi hidup manusia. Kehidupan mewah dan kemajuan ilmu pengetahuan dan teknologi tidak akan menjamin kebahagian manusia. Hal itu karena yang bisa menjamin kebahagian manusia tersebut adalah kejiwaan, kesehatan dan keberagamaan yang dimiliki manusia. Tiga faktor tersebut sangat sejalan sekali dalam mencapai kebahagian hidup manusia didunia dan akhirat, karena kebahagian yang harus dicapai itu tidak hanya kebahagian didunia melainkan juga kebahagian diakhirat kelak.

Banyak teori yang dikemukan oleh ahli jiwa tentang kesehatan mental, misalnya teori psikoanalisis, behavioris dan humamisme. Sungguhpun demikian teori tersebut memiliki batasan-batasan dan tidak menyentuh seluruh dimensi (aspek) dan aktivitas kehidupan manusia sebagai makhluk multidimensional dan multipotensial. Manusia sebagai makhluk multidimensional setidak-tidaknya memiliki dimensi jasmani, rohani, agama, akhlak, sosial, akal, dan seni (estetika). Sedangkan sebagai makhluk multi potensial manusia memiliki potensi yang amat banyak yang dikaruniakan Allah SWT kepadanya yang dalam islam terkandung dalam asma ulhusna. Salah satunya adalah agama. Agama adalah jalan utama menuju kesehatan mental, karena dalam agama ada kebuutuhan-kebutuhan jiwa manusia, kekuatan untuk mengendalikan manusia dla memenuhi kebutuhaan, serta sampai kepada kekuatan untuk menafikan pemenuhan kebuthan manusia tanpa membawa dampak psikologis yang negatif. ${ }^{10}$ 
Menurut Hasan Langgulung, kesehatan mental dapat disimpulkan sebagai "akhlak yang mulia". Oleh sebab itu, kesehatan mental didefinisikan sebagai "keadaan jiwa yang menyebabkan merasa rela (ikhlas) dan tentram ketika ia melakukan akhlak yang mulia.

Mental menurut islam yaitu, identik dengan ibadah atau pengembangan potensi diri yang dimiliki manusia dalam rangka pengabdian kepada Allah dan agama-Nya untuk mendapatkan Al-nafs Almuthmainnah (jiwa yang tenang dan bahagia) dengan kesempurnaan iman dalam hidupnya.

Sedangkan dalam bukunya Abdul Mujib dan Yusuf Mudzkir kesehatan menurut islam yang dkutip dari Musthafa fahmi, menemukan dua pola dalam mendefenisikan kesehatan mental: ${ }^{11}$

1. Pola negatif (salaby), bahwa kesehatan mental adalah terhindarnya seseorang dari neurosis (al-amhradh al-'ashabiyah) dan psikosis (al-amhradh al-dzihaniyah).

2. Pola positif (ijabiy), bahwa kesehatan mental adalah kemampuan individu dalam penyesuaian terhadap diri sendiri dan terhadap lingkungan sosial.

Islam sebagai suatu agama yang bertujuan untuk membahagiakan dan meningkatkan kualitas sumber daya manusia, sudah barang tentu dalam ajaranajaranya memiliki konsep kesehatan mental. Begitu juga dengan kerasulan Nabi Muhammad SAW adalah bertujuan untuk mendidik dan memperbaiki dan membersihkan serta mensucikan jiwa dan akhlak.

Di dalam Al-Qur'an sebagai dasar dan sumber ajaran islam banyak ditemui ayatayat yang berhubungan dengan ketenangan dan kebahagiaan jiwa sebagai hal yang prinsipil dalam kesehatan mental. Ayatayat tersebut adalah:

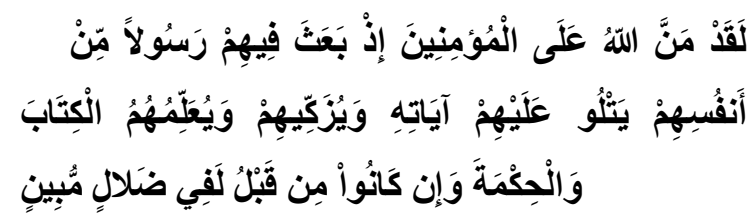

Artinya: Sungguh Allah telah memberi karunia kepada orang-orang yang beriman ketika Allah mengutus di antara mereka seorang rasul dari golongan mereka sendiri, yang membacakan kepada mereka ayat-ayat Allah, membersihkan (jiwa) mereka, dan mengajarkan kepada mereka alkitab dan al-hikmah. Dan sesungguhnya sebelum (keadaan nabi) itu, mereka adalah benar-benar dalam kesesatan yang nyata.

(Q.S. 3: 164)

Dalam hadits Rasulullah dijelaskan juga yaitu: 
Artinya: Sesungguhnya aku diutus oleh Allah adalah bertugas untuk menyempurnakan kemulian Akhlak manusia.

Dengan kejelasan ayat Al-Qur'an dan hadits diatas dapat ditegaskan bahwa kesehatan mental (shihiyat al nafs) dalam arti yang luas adalah tujuan dari risalah Nabi Muhammad SAW diangkat jadi rasul Allah SWT, karena asas, cirri, karakteristik dan sifat dari orang yang bermental itu terkandung dalam misi dan tujuan risalahnya. Dan juga dalam hal ini alQur'an berfungsi sebagai petunjuk, obat, rahmat dan mu'jizat (pengajaran) bagi kehidupan jiwa manusia dalam menuju kebahagian dan peningkatan kualitasnya sebagai mana yang ditegaskan dalam ayat berikut:

Artinya: Dan hendaklah ada di antara kamu segolongan umat yang menyeru kepada kebajikan, menyuruh kepada yang ma'ruf dan mencegah dari yang munkar; merekalah orang-orang yang beruntung. (Q.S. Ali Imran: 104)

Ayat di atas menjelaskan bahwa Allah menjanjikan kemenangan kepada orang-orang yang mengajak kepada kebaikan,menyuruh kepada yang makruf dan mencegah kapada yang mungkar. Keimanan,katqwaan,amal saleh, berbuat yang makruf, dan menjauhi perbuatan keji dan mungkar faktor yang penting dalam usaha pembinaan kesehatan mental.

Artinya: Dia-lah yang telah menurunkan ketenangan ke dalam hati orang-orang mukmin supaya keimanan mereka bertambah di samping keimanan mereka (yang telah ada). Dan kepunyaan Allah-lah tentara langit dan bumi dan adalah Allah Maha Mengetahui lagi Maha Bijaksana. (Q.S. Al-Fath: 4)

Ayat di atas menerangkan bahwa Allah mensifati diriNya bahwa Dia-lah Tuhan Yang Maha Mengetahui dan Bijaksana yang dapat memberikan ketenangan jiwa ke dalam hati orang yang beriman.

Artinya: Dan Kami turunkan dari Al Quran suatu yang menjadi penawar dan rahmat bagi orang-orang yang beriman dan AlQuran itu tidaklah menambah kepada orang-orang yang zalim selain kerugian. (Q.S. Al-Isra: 82)

Artinya: Hai manusia, sesungguhnya telah datang kepadamu pelajaran dari Tuhanmu dan penyembuh bagi penyakit penyakit (yang berada) dalam dada dan petunjuk serta rahmat bagi orang-orang yang beriman. (Q.S. Yunus: 57)

Berdasarkan kejelasan keterangan ayatayat Al-Qur'an diatas, maka dapat dikatakan bahwa semua misi dan tujuan 
Syi'ar Vol. 18 No. 1 Januari-Juni 2018

dari ajaran Al-Qur'an (islam) yang berintikan kepada akidah, ibadah, syariat, akhlak dan muamalata adalah bertujuan dan berperan bagi pembinaan dan pengembangan sumber daya manusia yang berkualitas dan berbahagia.

Islam memiliki konsep tersendiri dan khas tentang kesehatan mental. Pandangan islam tentang kesehatan jiwa berdasarkan atas prinsip keagamaan dan pemikiran falsafat yang terdapat dalam ajaran-ajaran islam.

Berdasarkan pemikiran diatas maka setidak-tidaknya ada enam prinsip keagamaan dan pemikiran filsafat yang mendasari konsep dan pemahaman islam tentang kesehatan jiwa yang dapat dijelaskan sebagai berikut:

1. Prinsip dan filsafat tentang maksud dan tujuan manusia dan alam jagad dijadikan oleh Allah SWT. Diantara maksud dan tujuan manusia dijadikan Allah adalah untuk beribadah dan menjadi khalifah di bumi.

2. Prinsip dan filsafat tentang keadaan sifat Allah dan hubungannya dengan sifat manusia. Dalam keyakinan islam Allah SWT memiliki sifat dan nama-nama yang agung, yakni asmaul husna yang jumlahnya ada 99 nama atau sifat.
3. Prinsip dan filsafat tentang keadaan amanah dan fungsi manusia dijadikan Allah sebagai khalifah di bumi. Manusia dijadikan Allah berfungsi sebagai khalifah di muka bumi. Sebagai khalifah Allah membekali manusia dengan dua kualitas (kemampuan), yakni ibadah dan siyadah atau imtak dan ipteks, agar manusia itu berhasil dalam mengelola bumi.

4. Prinsip dan filsafat tentang perjanjian (mistaq) antara manusia dan Allah sewaktu manusia masih berada dalam kandungan ibunya masing-masing. Allah menjadikan manusia dalam bentuk kejadian yang sebaik-baiknya, dan kemudian menyempurnakan kejadian dengan meniupkan ruh ke dalam tubuhnya (basyar), sehingga membuat para malaikat menaruh hormat yang tinggi kepada manusia.

5. Prinsip dan filsafat tentang manusia dan pendidikannya. Manusia dalam pandangan islam adalah makhluk multidimensional dan multipotensial.

6. Prinsip dan filsafat tentang hakikat manusia Dalam pandangan islam hakikat dari manusia itu adalah jiwanya, karena jiwa itu berasal dari 
Tuhan dan menjadi sumber kehidupan.

Berdasarkan pandangan dan pemikiran diatas, maka dapat dikemukakan pengertian kesehatan jiwa/mental dalam islam sebagai berikut. Kesehatan jiwa menurut islam tidak lain adalah ibadah yang amat luas atau pengembangan dimensi dan potensi yang dimiliki manusia dalam dirinya dalam rangka pengabdian kepada Allah yang diikuti dengan perasaan amanah, tanggung jawab serta kepatuhan dan ketaatan kepada Allah dan ajaran agama-Nya, sehingga dengan demikian terwujud nafsu muthmainnah atau jiwa sakinah.

\section{E. Kesehatan Mental dalam Khazana Pemikiran Islam}

Di samping itu dalam sejarah perkembangan pemikiran dalam islam tentang kejiwaan dan hidup kerohanian banyak pula ditemukan konsep islam tentang kesehatan jiwa (shihhat al nafs) yang ditulis oleh ulama klasik. Seperti:

Ibnu Rusyd mengartikan kesehatan jiwa itu dengan takwa. Dalam pengertian ini orang yang sangat sehat jiwanya adalah orang yang memiliki keimanan dan ketakwaan dalam kehidupan jiwanya. Takwa sebagai konsep kesehatan jiwa dalam islam bagi Ibnu Rasyd dapat dimaklumi dan dipahami, karena makna takwa itu luas dan tinggi.

Tegasnya Ibnu Rusyd mengatakan takwa adalah kesehatan jiwa dan hawa nafsu adalah unsure jiwa yang membuat kehidupan jiwa terganggu dan sakit. Kesehatan jiwa dalam arti takwa itu berasal dari Allah SWT.

Karena manusia sebagai khalifah menjadi wakil tuhan dimuka bumi yang memegang mandat tuhan untuk mewujudkan kemakmuran dimuka bumi kekuasaan yang diberikan bersifat kreatif, yang memungkinkan manusia mengelola serta mendayagunakan apa yang ada dibumi, untuk kepentingan hidupnya ${ }^{12}$

Hal tersebut sejalan dengan pendapat Muhammad Abduh yang menyatakan bahwa pembentukan dan penentuan kadar masing masing komponen yang ada pada manusia serta penciptaan anggota tubuhyang diladalmya ditanamkan potensi tertentu sehingga ia mampu melaksanakan fungsinya semua itu tidak mungkin dibiarkan tanpa ada " penjaga" yang mengawasi serta mengaturnya yaitu Allah $^{13}$

Adapun al-Ghazali mengistilahkan kesehatan jiwa itu dengan tazkiyat al nafs yang artinya identik dengan iman dan takwa sebagai yang telah dijelaskan. Ia mengartikan tazkiyat al nafs itu dengan 
ilmu penyakit jiwa dan sebab musababnya, serta ilmu tentang pembinaan dan pengembangan hidup kejiwaan manusia, suatu pengertian yang identik dengan kesehatan jiwa. Pengertian tersebut tidak terbatas pada konsepnya pada gangguan dan penyakit kejiwaan serta perawatan dan pengobatannya, tetapi juga meliputi pembinaan dan pengembangan jiwa manusia setinggi mungkin menuju kesehatan dan kesempurnaannya sesuai dengan arti kata tazkiyat itu sendiri dalam pendidikan al-Qur'an berikut: ${ }^{14}$

Artinya: demi jiwa dan kesempurnaan (ciptaan)-Nya. Allah menghilangkan kepada jiwa itu (jalan) kefasikan dan ketakwaan. Sesungguhnya beruntunglah orang yang melakukan proses tazkiyah (pembinaan takwa) dalam dirinya, sebaliknya merugilah orang-orang yang mengotori jiwa (mengikuti hawa nafsu dalam pembinaan jiwanya) atau tadsiyat al naf s. (Q.S. Asy Syamsu: 7-10)

Dari keterangan ayat diatas dapat pula diambil suatu pedoman bahwa tujuan dari pembinaan dan pengembangan jiwa itu dalam islam adalah untuk mewujudkan kondisi kesehatan jiwa yang baik. (alfalah) yang diperoleh melalui pendidikan tazkiyah atau pembinaan potensi jiwa takwa dalam diri. Adanya penjelasan tentang segi positif manusia yang terungkap dalam al qur'an harus difahami bahwa semua itu menunjukan beberapa kelemahan manusia yang harus dihindari ${ }^{15}$

Dengan demikian kesehatan jiwa itu juga identik bagi al-Ghazali dengan keimanan dan ketakwaan dalam arti tazkiyat al nafs. Dari uraian yang telah dikemukakan di atas dapat ditegaskan bahwa iman dan takwa memiliki relevansi yang sangat erat sekali dengan soal kejiwaan. Iman dan takwa itulah arti psikologi dan kesehatan mental yang sesungguhnya bagi manusia dalam Islam.

Karena manusia telah diberi kepercayaan untuk mengelola bumi dan karenanya mesti mengetahui seluk beluk bumi, atau paling tidak punya potensi untuk mengetahui ${ }^{16}$

\section{F. Kesimpulan}

Kesehatan mental dalam kehidupan manusia merupakan masalah yang amat penting karena menyangkut soal kualitas dan kebahagian manusia. Tanpa kesehatan yang baik orang tidak akan mungkin mendapatkan kebahagian dan kualitas sumber daya manusia yang tinggi.

Hal itu karena yang bisa menjamin kebahagian manusia tersebut adalah kejiwaan, kesehatan dan keberagamaan yang dimiliki manusia. Tiga faktor tersebut sangat sejalan sekali dalam mencapai 
kebahagian hidup manusia didunia dan akhirat, karena kebahagian yang harus dicapai itu tidak hanya kebahagian didunia melainkan juga kebahagian diakhirat kelak.

Islam memiliki konsep tersendiri dan khas tentang kesehatan mental. Pandangan islam tentang kesehatan jiwa berdasarkan atas prinsip keagamaan dan pemikiran falsafat yang terdapat dalam ajaran-ajaran islam. Berdasarkan pemikiran diatas maka setidak-tidaknya ada enam prinsip keagamaan dan pemikiran filsafat yang mendasari konsep dan pemahaman islam tentang kesehatan jiwa. dapat ditegaskan bahwa iman dan takwa memiliki relevansi yang sangat erat sekali dengan soal kejiwaan. Iman dan takwa itulah arti psikologi dan kesehatan mental yang sesungguhnya bagi manusia dalam Islam

\section{Endnote}

1 Hanna Jumhana, Integrasi Psikologi dengan Islam menuju Psikologi Islami, (Yogyakarta: Pustaka Pelajar,2001) Cet II.h. 50

${ }^{2}$ Adi Warsito, Manusia Dalam Pandangan al qur'an,Word Press, 2010

${ }^{3}$ Jarvis Matt, Teori Teori Psikologi (Pendekatan Modern untuk memahami perilaku dan pikiran manusia) Terjemahan SPA- Team work Nuansa Bandung

${ }^{4}$ Bimo Wagito, Pengantar Psikologi, (penerbit ANDI Yogyakarta), hal. 229

${ }^{5}$ Alex Sobur,,Psikolog Umum,Bandung,Pusaka Setia,2003),hal.407-409

${ }^{6}$ Prof.Dr.Bimo Wagito, Pengantar Psikologi,(penerbit ANDI Yogyakarta), hal.133

${ }^{7}$ Daradjat, Zakiah. Kesehatan Mental (Jakarta : Gunung Agung, 1995).hlm :45

${ }^{8}$ Sutarjo Wiramiharja, Pengantar Psikologi abnormal,2005(Bandung: Refika Aditama),h.9-10

${ }^{9}$ Isep Zainal Arifin, Bimbingan Penyuluhan Islam(Jakarta:Raja Grafindo,2011)h.26

${ }^{10}$ Sururin, Ilmu Jiwa Agama, Jakarta: PT. Raja Grafindo Persada, 2004 Hal 4

${ }^{11}$ Nuansa-nuansa Psikologi Islam, Abdul Mujib, M.Ag. Jusuf Mudzakir, M.Si

http://arrisalah.org/main/content/view/49/28/

\author{
${ }^{12}$ Musa Asyarie, Manusia Pembentuk Kebudayaaan \\ dalam alqur'an, (Yogyakarta:LESFI,1991)h.43 \\ ${ }^{13}$ Muhammad Abduh, Tafsir Juz ama,(Bandung: \\ Mizan, 1999)h.27 \\ ${ }^{14}$ Usman Najati, Psikologi Dalam Al-quran, \\ (Bandung,Pusaka Setia,2005),hal.99 \\ ${ }^{15}$ Rif'at Syauqi,Konsep Manusia Menurut Al qur'an \\ dalam metodologi Psikologi Islam,(Yogyakarta: Pustaka \\ Pelajar,2000)h.8 \\ ${ }^{16}$ Machsin, Menyelami Kebebasan Manusia telaah kritis \\ terhadap konsepsi al qur'an, (Yogyakarta:Pustaka \\ Pelajar,1996) h.8
}



